\title{
PLAN AHEAD
}

\author{
Spring Meeting \\ 24-27 April 1997 \\ Vanderbilt University, Nashville, Tennessee
}

Proposals for papers, sessions, moderators, and respondents are welcomed by the Program Committee. Send all suggestions and offers to:

Professor Dale A. Johnson

Vanderbilt Divinity School

Nashville, TN 37240

\section{PLAN AHEAD}

\author{
Winter Meeting \\ 2-5 January 1997 \\ New York, New York
}

Proposals for papers, sessions, moderators, and respondents are welcomed by the Program Committee. Send all suggestions and offers to:

\author{
Professor Barbara Brown Zikmund \\ Hartford Seminary \\ 77 Sherman Street \\ Hartford, CT 06105
}




\title{
THE PEW CHARITABLE TRUSTS
}

\section{Research Advancement Grants for Projects on Christian Mission and World Christianity}

The Religion Program of The Pew Charitable Trusts invites proposals for large-scale projects that will enhance team research and publication in studies of Christian Mission and non-Western Christianity. Grants will be made on a competitive basis for two- to three-year collaborative projects that will contribute significantly to the advancement of scholarship on cross-cultural mission and/or the development of Christianity in the southern and eastern continents. Grants will range from $\$ 50,000$ to $\$ 100,000$ (U.S.) per year.

Projects should be directed by one or more established scholars, have access to appropriate research facilities, involve scholars from two or more regions of the world, and contribute to the intellectual and cross-cultural vitality of the global Christian movement. Projects that are interdenominational and interdisciplinary and that elicit significant contributions from the non-Western world are particularly welcome. Two or three grants will be awarded at the end of 1996 , subject to the quality of proposals received and the availability of funds.

The deadline for receiving initial proposals (maximum four pages) for 1996 Research Advancement Grants is May 15, 1996. For further information and instructions please contact:

\author{
Geoffrey A. Little, Coordinator \\ Research Advancement Grants \\ Overseas Ministries Study Center \\ 490 Prospect Street \\ New Haven, Connecticut 06511-2196 \\ U.S.A \\ Tel: (203) 865-1827 \\ Fax: (203) 865-2857
}




\section{The Making of a Heretic}

Gender, Autbority, and the Priscillianist

Controversy

Virginia Burrus

Silenced for 1,600 years, the "heretics" speak for themselves in this account of the Priscillianist controversy that began in fourth-century Spain. Burrus provides an unusual opportunity to explore heresy from the point of view of the followers of Priscillian and to reevaluate the reliability of the historical record.

Transformation of the Classical Heritage, $\$ 45.00$ cloth

At bookstores or order $1-800-822-6657$

UNIVERSITY OF CALIFORNIA PRESS

\section{Symeon the Holy Fool}

Leontius's Life and the Late Antique City Derek Krueger

Here one of the most colorful of early Christian saints is brought to life.

Krueger fleshes out a broad picture of the religious, intellectual, and social environment in which the Life was created and opens a window onto the Christian religious imagination at the end of Late Antiquity.

Transformation of the Classical Heritage, $\$ 35.00$ cloth

\section{Congratulations Elisabeth G. Gleason author of Gasparo Contarini Venice, Rome, and Reform winner of the \\ HOWARD R. MARRARO PRIZE of the American Catbolic Historical Association $\$ 35.00$ cloth}

\section{The complete history of the Crusades}

Ranging from the First Crusade in 1095 to today's legacy of crusading ideals and imagery, this authoritatively written volume provides a comprehensive history of Europe's Holy War with the Muslim world. Based on the latest research and packed with hundreds of informative illustrations-as well as maps, chronologies, and a guide to further reading - this thoughtful volume will interest anyone with a serious interest in the Crusades. 


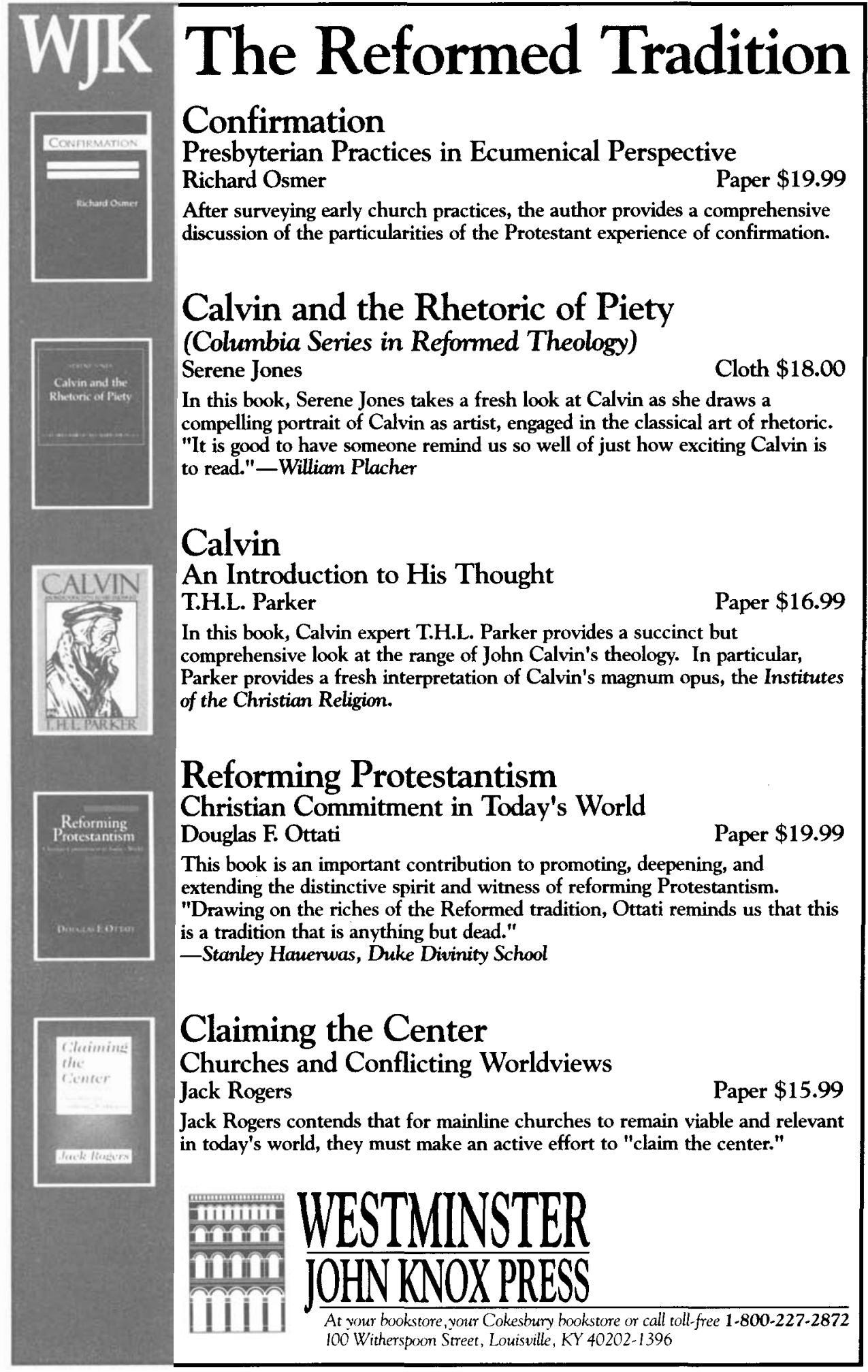




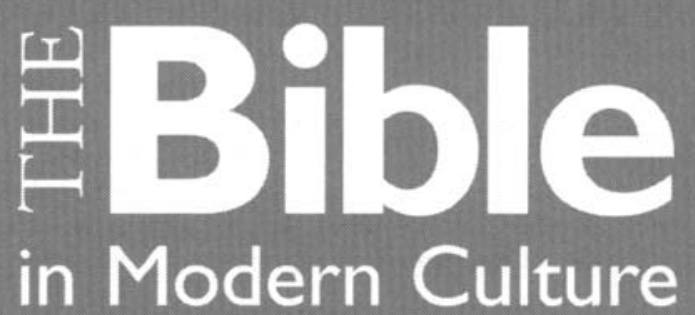

Theology and

Historical-Critical

Method

from Spinoza

to Käsemann

\section{ROY A. HARRISVILLE \& WALTER SUNDBERG}

"The Bible in Modern Culture is a first-rate contribution. It is a book deeply engaged with the history of German biblical scholarship and so a useful roadmap for those (especially in the study of the New Testament) who have taken their bearings primarily from the English and the Scots.... The book testifies eloquently to the ability of Augustinian convictions to transcend, even while absorbing, the Enlightenment assumptions that have dominated academic study of the Bible for the last two centuries."

-MARK NOLL

"The most important issue for theology and the church in our time is the recovery of a dynamic role for the Scriptures in the concrete lives of our pastors and people in the era of the historical criticism of the Bible. In wrestling with this issue, pastors, theologians, and historians alike will find no better presentation of the background and the personalities than this sweeping panorama by Harrisville and Sundberg."

-PAUL ROREM

"Whether or not one agrees with all of the assessments set forth in this volume, a careful study of it can serve to help clarify the proper relation between modern historical-criticism and the apostolic faith of the church. I would especially recommend the volume to evangelicals who wish to better understand that relationship." -ELIZABETH ACHTEMEIER

\section{ISBN 0-8028-0873-5 $\bullet 293$ pages $・$ Paperback $\bullet \$ 20.00$}

\section{At your bookstore, or call 800-253-7521 FAX 616-459-6540}




\section{"If you have only one church history book, this should be it.}

No other survey so attractively combines accuracy and readability with an abundance of well-chosen illustrations. It will please both those who like to read about the past and those who never knew how interesting it could be." - Christianity Today

\section{INTRODUCTION TO THE HISTORY OF CHRISTIANITY}

TIM DOWLEY, Editor

688 pages $0-8006-2935-3$ Code 1-2935 $400+$ photographs, color and b/w; 30 maps, charts, diagrams $\$ 42.00(\$ 56.75)$

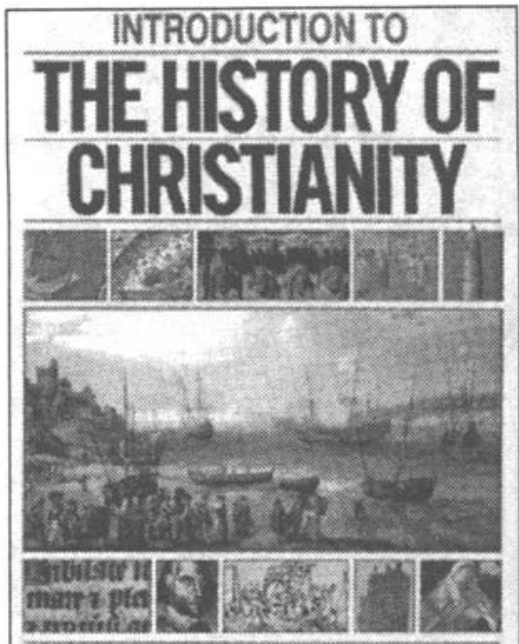

FIRSY CESTURY TO THE PAESENT OAF - $A$ WORLOWIOE STOAY PEOPLE AAD MOYEMEATS 400 PICTUAES, MA?5, DIAGRAMS EDITED BY THM DOWUEY

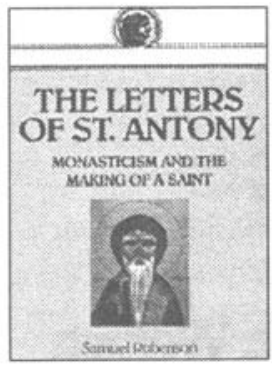

\section{THE LETTERS} OF ST. ANTONY

Monasticism and the Making of a Saint SAMUEL RUBENSON By means of a fresh analysis of the letters of $\mathrm{St}$. Antony, Rubenson describes the desert monasteries as centers of theological reflection in Egypt, showing how they combined the specularive philosophy of the Greeks and the biblical tradition. Studies in Antiquity and Christianity

256 pages paper ISBN 0-8006-2910-8

Code 1-2910

$\$ 19.00(\$ 25.75)$

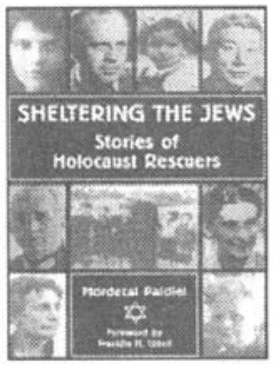

\section{SHELTERING THE JEWS \\ Stories of}

Holocaust Rescuers

MORDECAI PALDIEL

Foreword by Franklin $\mathrm{H}$. Littell. From the riveting testimonies and files housed at Yad Vashem, the Holocaust martyrs and heroes memorial in Jerusalem, Paldiel highlights the radical altruism, courage, and ingenuity of non-Jews that helped some Jews to survive the darkest moment in history. Includes an 8-page photo gallery.

200 pages paper ISBN 0-8006-2897-7

Code 1-2897

$\$ 16.00$ (\$21.75)

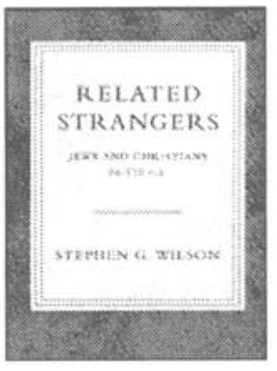

\section{RELATED}

STRANGERS

Jews and Christians, 70-170 C.E

STEPHEN G. WILSON

"An independent, up-todate, and nuanced analysis of a crucially important but scill neglected period in the history of Judaism and early Christianiry. This will become the standard treatment for the next generation." - PETER RICHARDSON

336 pages paper

ISBN 0-8006-2950-7

Code 1-2950

$\$ 26.00$ (\$35.25)

\section{AFTER THE APOSTLES}

Christianity in the Second Century WALTER $H$. WAGNER

"A concise and accessible treatment of key thinkers and issues in second-century Christianity, written in a clear and readable style."

- HAROLD W. ATTRIDGE

296 pages paper

ISBN 0-8006-2567-6

Code 1-2567

$\$ 17.00(\$ 22.95)$ 
MEN IFROMN UMDIAMA

Hurrying toward Zon

Universities, Divinity Schools, and

American Protestantism

\section{Conrad Cherry}

". .. an engaging story, filled with colorful characters, punctuated by conflict, and deepened by Cherry's wonderful sense for the complexity of human motives and institutions" -Brooks Holifield, Emory University

"The archival research is exhaustive and the prose always lucid and engaging ... this book is certain to stand as the standard for this most important subject. "- Harry S. Stout, Yale University

The colorful study of university divinity schools in American.

392 pages cloth $\$ 24.95$

\section{Cod's Government Begun}

The Society for Universal Inquiry and Reform, 1842-1846

\section{Thomas D. Hamm}

A study of radical utopian communities in antebellum America. Growing out of the most radical fringes of the abolitionist movernent, the Society for Universal Inquiry and Reform set out to inaugurate a new social order based on the principles of nonresistance.

Religion in North America

\section{4 pages}

cloth $\$ 39.95$

\section{Hoosier Faiths}

A History of Indiana's Churches and Religious Groups

\section{C. Rudolph}

This maiqur reference work surveys the history of more than fifty denominations and religious groups in Indiana from pioneer days to the present. L. C. Rudolph describes the founding and development of each religious group.

highights major personalities and issues, and summarizes the group's present status.

752 pages, 32 b8w photos cloth $\$ 39.95$

\section{Married to the Church}

Raymond Hedin

What a wonderful book... The analysis of thase who left the priesthood is the most penetrating lve ever seen on the subject." -Fr. Andrew M. Greeley

"Starting, methodalogically important, and quite moving. .... a firstrate work of religious and cuttural analysis." - Robert Orsi, author of The Madonna of 115th Street

A moving and insightful look at a generation of men trained for the priesthood.

\section{2 pages}

cloth $\$ 29.95$

\section{Being Right}

Conservative Catholics in America

Edited by Mary Jo Weaver

and R. Scott Appleby

"At in-depth look at these groups, both as they see themseves and as they appear to trained scholars." - David J. OBrien, College of Holy Cross A multifaceted look inside the world of conservative American Catholics.

\section{8 pages}

paper $\mathbf{\$ 1 8 . 9 5}$ [also in cloth \$39.95]

Now back in print!

\section{New Catholic Women}

A Contemporary Challenge to

Traditional Religious Authority

Mary Jo Weaver

"Mary Jo Weaver has charted the course of this new consciousness among Roman Catholic women." -Rosemary Radford Ruether

"This is the first full-scale study of how the U.S. women's movement has intersected with the Wes and aspirations of American Roman Catholic women" -Elizabeth Johrson, Religious Sucties Review

\section{8 pages}

paper $\$ 14.95$ (alse in cloth $\$ 24.95$ )

\section{At bookstores or from}

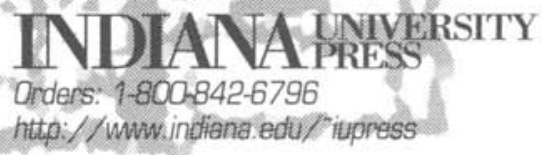




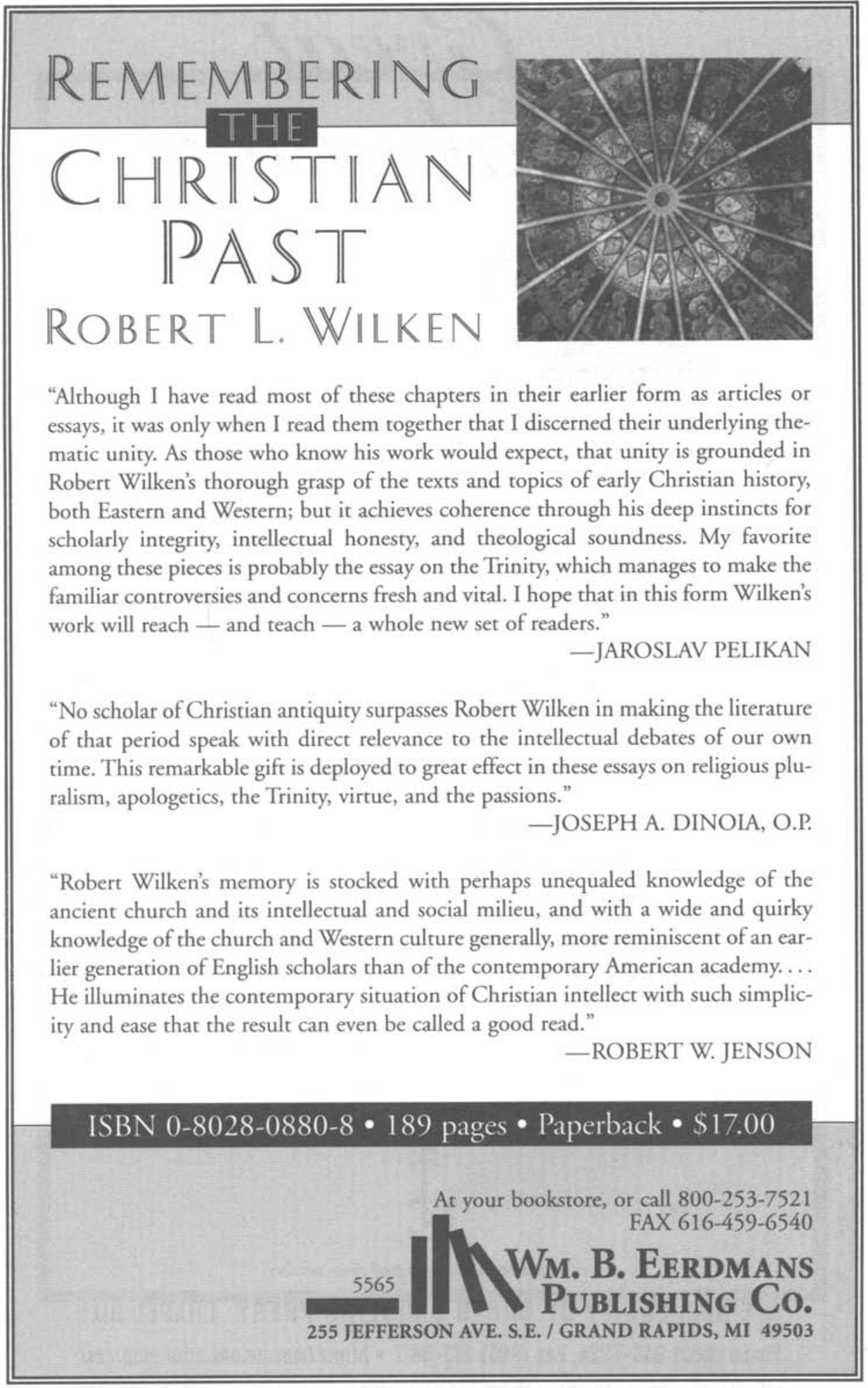




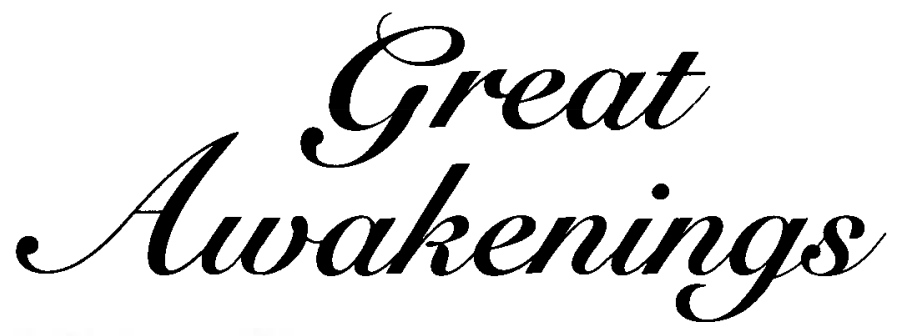

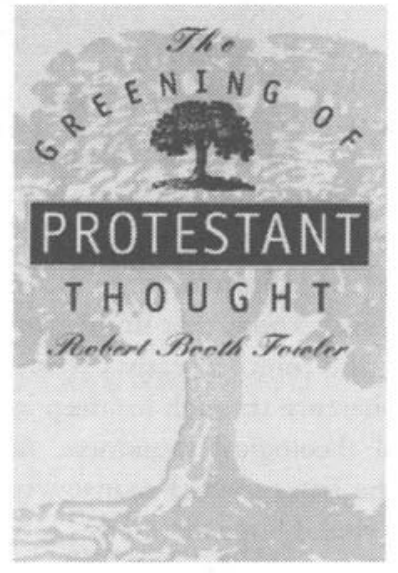

The Greening of Protestant Thought

by Robert Booth Fowler

Explores the theological, political, and policy debates within U.S. Protestant thought from 1970 to 1990 conceming the environment and environmental crises. 252 pp., $\$ 34.95$ cloth, $\$ 14.95$ paper

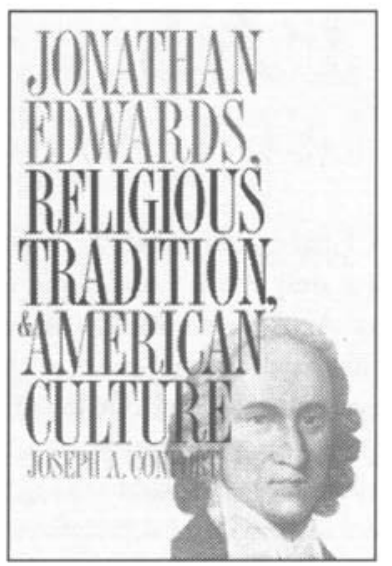

Jonathan Edwards, Religious Tradition, and American Culture by Joseph A. Conforti

"[Conforti] explains fully the wide appeal of this difficult thinker for his nineteenth-century audiences, illustrating how Edwards became something new and different when his texts were transformed into artifacts of emergent popular culture."-Philip F. Gura, University of North Carolina at Chapel Hill 288 pp., \$29.95 cloth, \$13.95 paper

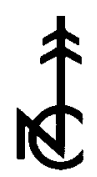

at bookstores or by tolly free order 


\section{NOW AVAILABLE}

\section{CHURCH HISTORY INDEX, 1981-1990 (Volume 4)}

Includes index of all articles by author, title, and subject and all book reviews by title, author index, and reviewer which were published in CHURCH HISTORY from 1981-1990

$$
275 \text { pages }
$$

$\$ 12.00$ (including postage)

A limited number of previously published volumes of the $\mathrm{CHURCH}$ HISTORY INDEX are still available at $\$ 12.00$ each including postage:

$$
\begin{aligned}
& \text { Volume } 1,1889-1961 \text { - no longer available } \\
& \text { Volume 2, 1962-1970 - } 107 \text { pages } \\
& \text { Volume 3, 1971-1980 - } 179 \text { pages }
\end{aligned}
$$

Requests for copies, with covering remittance, should be forwarded to:

Henry W. Bowden

American Society of Church History

P.O. Box 8517

Red Bank, NJ 07701 


\section{AMERICAN SOCIETY OF CHURCH HISTORY \\ Membership Information}

The American Society of Church History was founded in 1888 by Philip Schaff and a group of colleagues. It is affiliated with the American Historical Association. Its purpose is to foster interest in the history of Christianity, and its interrelationship with its cultural context by encouraging research, writing, and teaching in this discipline.

The membership of the society consists of scholars, men and women, the majority of whom serve on faculties of colleges, universities, and seminaries. Others are archivists, clergy members, professional writers, and students, or simply those who have a serious interest in church history. The society is ecumenical in character, comprising members of various religious persuasions.

In addition to Church History, a journal published quarterly, the society holds an annual meeting in conjunction with the American Historical Association and a spring meeting on the campus of a host institution. The meeting programs and the journal provide opportunities for exploring a wide variety of subjects and the exchange of thought. Membership dues entitle one to receive the journal, with its informative articles and large book review section, and attend the meetings of the society.

In order to interest younger scholars, particularly those of ethnic minorities, in the work of the society, the council has voted to offer a dues-free membership (up to two years) to all graduate students working in the area of church history at an accredited institution upon the approval of a professor who is also a member of the society.

Application for Membership

American Society of Church History

$\begin{array}{llll}\text { Name: last } & \text { first } & \text { middle }\end{array}$

\begin{tabular}{lllll}
\hline Address: & street & city & state & zip
\end{tabular}

Present institutional affiliation/Last degree earned-when and where

Annual dues are $\$ 30.00$, plus $\$ 7.00$ foreign postage, including Canada. Graduate students working in the area of church history with the approval and verification of a professor who is also a member of the society may join without paying a fee. Persons who have been members of the society for at least five years and are now retired from professional life may continue membership at $\$ 15.00$ per year. Membership in the society includes a subscription to Church History. The council approves applications at its semiannual meetings.

Send to: Henry W. Bowden, P.O. Box 8517, Red Bank, NJ 07701. 


\section{PRIZES OF THE AMERICAN SOCIETY OF CHURCH HISTORY}

\section{The Frank S. and Elizabeth D. Brewer Prize}

The Frank S. and Ellzabeth D. Brewer Prize, offered annually, is a subvention fund of $\$ 1000$ to assist a press in publishing a book-length manuscript in church history. The Brewer Prize is limited to first books. Manuscripts already accepted for publication may be submitted for this award, but the publication must have printed on its title-page, "The Frank S. and Elizabeth D. Brewer Prize Essay of the American Society of Church History." The monetary grant will be authorized upon receipt in writing of a commitment from a publisher accepting the manuscript. Complete manuscripts in final form must be received by Henry W. Bowden, P.O. Box 8517, Red Bank, NJ 07701, by 1 November. Manuscripts may not be submitted in more than one ASCH competition. The award will be announced at the Spring meeting of the Society. No award will be made in any year when none of the manuscripts is adjudged to be outstanding.

Winner for 1994: Stephen Burnett "From the Jews' Own Books: Johann Buxtorf, Christian Hebraism, and the Emergence of Jewish Studies."

Winner for 1993: Diana Hochstedt Butler, "Standing Against the Whirlwind: A Study of the Evangelical Party in the Protestant Episcopal Church."

Winner for 1992: Gregory Hanlon, "Confession and Community in SeventeenthCentury France: Catholics and Protestants in Acquitaine."

\section{The Philip Schaff Prize}

The Philip Schaff Prize is an award in the amount of $\$ 1000$ to be paid to the author of the best book originating in the North American scholarly community which presents original research in the history of Christianity or any period thereof. This award is given in odd-numbered years. Books published during the two previous calendar years are eligible for the competition. Any member of the Society may nominate titles for consideration. Copies of nominated books need not be submitted. Titles of nominated books must be received by Henry W. Bowden, P.O. Box 8517, Red Bank, NJ 07701 by 1 March in odd-numbered years. The prize will be announced at the annual Winter meeting of the Society.

Winner for 1993: Stephen J. Stein, The Shaker Experience in America.

Winner for 1991: David D. Hall, Worlds of Wonder, Days of Judgment: Popular Religious Belief in Early New England.

\section{The Sidney E. Mead Prize}

The Sidney E. Mead Prize is an award in the amount of $\$ 250$ for the author of the best unpublished essay in any field of church history written by a doctoral candidate or recent recipient whose manuscript stems directly from doctoral research. The manuscript will be published in Church History. Entries of no more than twenty-five double-spaced pages, including double-spaced endnotes, must be submitted to Henry W. Bowden, P.O. Box 8517, Red Bank, NJ 07701, by 1 July. The prize is offered annually, though no award will be made in any year when none of the manuscripts is adjudged to be outstanding. Manuscripts may not be submitted in more than one ASCH competition. The winner will be announced at the annual Winter meeting of the Society.

Winner for 1992: Alison Williams Lewin, "'Cum Status Ecclesie Noster Sit . . . Florence and the Council of Pisa (1409)."

Winner for 1991: Ernest Freeburg, "'An Object of Peculiar Interest': The Education of Laura Bridgman." 


\section{THE ALBERT C. OUTLER PRIZE IN ECUMENICAL CHURCH HISTORY}

The Albert C. Outler Prize in Ecumenical Church History consists of an award of $\$ 1000$ to the author of a book-length manuscript and a possible grant of up to $\$ 3000$ for publication costs - or in exceptional cases, for necessary expenses in the preparation of a manuscript accepted for publication. The term "Ecumenical" is to be construed as chiefly concerned with the problems of Christian unity and disunity (doctrinal, cultural, institutional) in any period of church history, or with interactions between Christianity and other religious movements. Works of a partisan nature are excluded. The winning manuscript must have printed on its title-page, "The Albert C. Outler Prize in Ecumenical History of the American Society of Church History." Complete manuscripts in final form must be received by Henry W. Bowden, P.O. Box 8517, Red Bank, NJ 07701, by 1 June. The prize is offered annually, though no award will be made in any year when none of the manuscripts is adjudged to be outstanding. Manuscripts may not be submitted in more than one ASCH competition. The winner will be announced at the annual Winter meeting of the Society.

Winner 1993: Allen C. Guelzo, For the Union of Evangelical Christendom: The Irony of the Reformed Episcopalians, 1873-1930.

Winner for 1991: Ronald L. Numbers, The Creationists.

\section{THE JANE DEMPSEY DOUGLASS PRIZE}

The Jane Dempsey Douglass Prize is an award in the amount of $\$ 250$ for the author of the best unpublished essay on some aspect of the role of women in the history of Christianity. The manuscript will be published in Church History. Entries of no more than twenty-five double-spaced pages, including doubled-spaced endnotes, must be submitted to Henry W. Bowden, P.O. Box 8517, Red Bank, NJ 07701, by 1 August each year. The prize is offered annually, though no award will be made in any year when none of the manuscripts is adjudged to be outstanding. Manuscripts may not be submitted in more than one ASCH competition. The winner will be announced at the annual Winter meeting of the Society.

Winner for 1993: Genevieve McCoy, "Post-Edwardian Calvinism and the Women of the ABCFM Oregon Mission."

Winner for 1991: Joyce Irwin, "Pietism and Women: A Study in Contrasts." 


\section{American Society of Church History}

\section{Request for a Proposal}

\section{To provide for the editorial operations of Church History after the September 1997 issue}

Goals:

- To maintain Church History as a leading journal in the study of religious history

- To enable younger scholars to benefit from the journal for their professional development

- To advance scholarship in the history of Christianity in all parts of the world

Individuals and institutions interested in assuming editorial oversight for Church History should prepare a proposal that addresses the following questions:

(1) How will scholarly familiarity with the full range of materials which might be published in Church History be maintained? (Multiple editors or consultants?) Please enclose a resume for each person who will play a major editorial role.

(2) How will younger scholars and graduate students have an opportunity to benefit from working for the journal, learning the field, and knowing current literature?

(3) How will support services be provided in the form of ...
a) Released time for secretarial/editorial services
b) Graduate assistants
c) Office space, heat, electricity, etc.
d) Mail service, copiers, telephone, fax, e-mail?

(4) How would you propose to make use of an editorial board?

(5) How will the new editorial leadership seek to change or maintain the journal? What challenges do you think are facing this journal? Should the title be changed? Should certain editorial policies be changed? Why? How should book reviews be handled?

(6) Are you (and others involved) willing to take on this responsibility for a term of five years?

\section{Send FIVE COPIES of your proposal by June 1, 1996 to:}

John F. Wilson

The Graduate School Office

205 Nassau Hall

Princeton, NJ 08544
FAX: (609) 258-6180

E-mail: jfwilson@pucc.princeton.edu 